\title{
Efficacy and safety of glue assisted suture less trans-scleral fixation of posterior chamber intraocular lens (SF- PCIOL)
}

\author{
Geetika Srivastava ${ }^{1}$, Navratan Goel ${ }^{2, *}$, Anshu Arora ${ }^{3}$ \\ ${ }^{1}$ Senior Resident, ${ }^{2}$ Consultant, ${ }^{3}$ Senior Consultant, ${ }^{1}$ GMERS Medical College, Himmatnagar, Gujarat, ${ }^{2}$ Eagle eye Hospital, \\ Yamuna Vihar, New Delhi, ${ }^{3}$ Vision First Eye Centre, Noida, Uttar Pradesh, India
}

*Corresponding Author:

Email: geetshri556@gmail.com

\begin{abstract}
Context: Scleral-fixated posterior chamber lens implantation (SF-PCIOL) in eyes without sufficient capsular support remains a widely applied surgical procedure. Suture - less scleral IOL fixation, Is a new technique in which PC IOL is placed in eyes with deficient posterior capsule and the haptics are incarcerated in the scleral pocket which is sealed with quick-acting fibrin glue.

Aims and Objectives: To evaluate the efficacy and feasibility of fibrin glue-assisted posterior chamber intraocular lens (IOL) implantation method in post cataract surgery.

Material and Methods: The study includes 10 Patients presented with inadequate capsular support who underwent Glue assisted SF-PCIOL over a time period of 12 months at a tertiary care eye hospital. Statistical analysis was done on Microsoft excel.

Results: In present study of ten eyes the final postoperative BCVA at $3^{\text {rd }}$ month was improved or remained same in nine (90\%) patients and only one patient had reduced BCVA.

Conclusion: Lots of complications are encountered with the use of sutures in the operative procedures; bio-adhesives fibrin glue have emerged as a viable alternative for glue assisted suture less transscleral fixation of posterior chamber intraocular lens (SFPCIOL), over the last three decades.
\end{abstract}

Keywords: Scleral-Fixated Posterior Chamber IOL (SF-PCIOL), haptics, Fibrin glue, Best Corrected Visual Acuity (BCVA).

\section{Introduction}

Implantation of intraocular lenses (IOL) has become the standard of care in the post cataract surgery; in some instances IOL implantation is not possible, for example surgical complications of cataract surgery, weakness of capsular / zonular support and in congenital weakness of the lens zonules. ${ }^{1}$ In these cases, several other methods are used; like anterior chamber angle and iris fixated lenses, as well as posterior chamber iris fixated and sclera fixated posterior chamber intra ocular lenses (SF-PCIOL). ${ }^{2}$

Anterior chamber lenses cause a variety of complications, such as progressive loss of corneal endothelial cells with consecutive corneal edema, glaucoma, uveitis, and cystoid macular edema. ${ }^{3,4}$ Posterior chamber intra ocular lenses (PCIOL) possess the inherent advantages of having a position close to the nodal point of the eye and also of being close to the eye's rotational axis. ${ }^{5,6}$ They reduce the chances of retinal detachment, cystoid macular edema and reduces chances of anterior segment neovascularization by less diffusion of vasoactive substances in diabetics. ${ }^{7}$ Scleralfixated posterior chamber lens implantation (SFPCIOL) in eyes without sufficient capsular support remains a widely applied surgical procedure.

Sutured SF-PCIOL implantation carries the risk of multiple complications, including suture induced inflammation, suture degradation, and delayed IOL subluxation and dislocation due to broken suture. ${ }^{8}$ The technique also requires surgical expertise and is timeconsuming. To prevent these obstacles and complications, it is worthwhile to look a procedure where suture is not required..$^{9-11}$ Recently a technique developed by Agarwal et al $^{12}$ to attach the IOL using biological fibrin glue. In this new technique PC IOL is placed in eyes with deficient posterior capsule and the haptics are incarcerated in the scleral pocket which is sealed with quick-acting surgical fibrin sealant derived from human blood plasma, with both haemostasis and adhesive properties and act as adjunct to wound healing. ${ }^{13-15}$

Present study was conducted with the objectives to assess efficacy and feasibility of this new method.

\section{Material and Methods}

The present study was conducted at ICARE eye hospital \& Post Graduate Institute, a tertiary care eye hospital located in NOIDA over a period of 12 months (January 2011 to December 2011). In this observational study ten patients presenting with inadequate capsular support who underwent Glue assisted SF-PCIOL have been considered. Prior approval was taken from institutional ethics committee. Statistical analysis was done on Microsoft excel.

Inclusion criteria: Aphakic or subluxated/dislocated cataractous lens or subluxated/ dislocated posterior chamber intraocular lens (PCIOL) with deficient or absent capsular support, BCVA $\geq 6 / 12$.

Exclusion criteria: Uncontrolled Diabetes mellitus \& Hypertension ,Serious cardiac problems, Low endothelial cell count $\left(\leq 1500\right.$ cells $\left./ \mathrm{mm}^{3}\right)$, Corneal opacity, Glaucoma ,Posterior uveitis, Serious posterior segment pathology ,History of prolong topical or 
systemic steroid use, Primary surgical intervention at least 3 months back.

Informed consent was taken in each case. Full pre and post operative evaluation including best corrected visual acuity (BCVA), Refraction, intraocular pressure (IOP) measurement by applanation tonometry, slit lamp examination and fundus examination, specular microscopy (endothelial cell count), corneal topography, central macular thickness was done.

In all the cases standard procedures of vitrectomy (anterior or pars plana vitrectomy) and Glue assisted suture less transscleral fixation of posterior chamber intraocular lens was followed. Postoperatively, they were followed at regular interval at post op Day $1,1^{\text {st }}$ week, $6^{\text {th }}$ week and $3^{\text {rd }}$ month. Snellen visual acuity was converted to logarithm of the minimum angle of resolution ( $\log$ MAR) units and decimal equivalent for statistical analysis. In refractive analysis minus cylinder was converted to plus cylinder form for uniformity. Fibrin glue consists of two main components: Fibrinogen (human) and Thrombin (human). These two components of the sealant were applied by simultaneous application using duploject and application Needle (Fig. 1). After the equal volumes 2 components were applied, the glued parts were held in the desired position for 3 or 5 minutes to ensure that the setting Sealant adheres firmly to the surrounding tissue. (Solidified Sealant reaches its ultimate strength after about 2 hours.)

Peribulbar block under all aseptic precautions. Two partial thickness limbal-based scleral flaps of approximately $2.5 \mathrm{~mm}$ x $3.0 \mathrm{~mm}$ were created exactly 180 degree diagonally apart and about $1.5 \mathrm{~mm}$ from the limbus. Followed by vitrectomy via either pars plana or the anterior route to remove all vitreous traction. Using a $22 \mathrm{G}$ needle, two straight sclerotomies were made under the existing scleral flaps, about $1.5 \mathrm{~mm}$ from the limbus. Scleral/corneal tunnel incision for introducing the IOL was made about $2 \mathrm{~mm}$ from the limbus. IOL was introduced with McPherson forceps and tip of the leading haptic was grasped with the microrhexis forceps and pulled through the inferior sclerotomy following the curve of the haptic and externalized under the inferior scleral flap. Similarly, the trailing haptic also externalized through the superior sclerotomy under the scleral flap. The reconstituted fibrin glue then injected under the superior and inferior scleral flaps. Pressure applied locally over the flaps for about 10 to 20 seconds to aid the formation of fibrin polypeptides. Pad and bandage with antibiotic ointment for $24 \mathrm{hr}$.

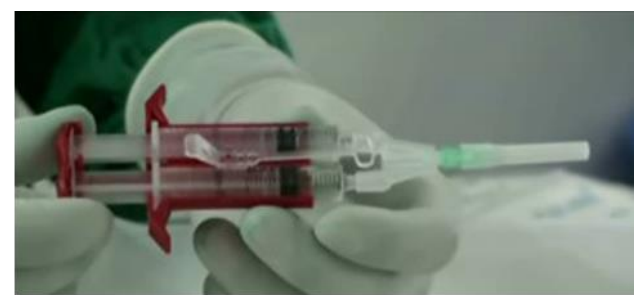

Fig. 1: Duploject \& Application needle

\section{Results and Observations}

Out of total ten patients 7 were male and 3 were female (Fig. 2). Male and female ratio was 2.3:1 in present study. Age group distribution shows that maximum number of patients are of $>60$ years (Table 1).

\section{GENDER DISTRIBUTION}

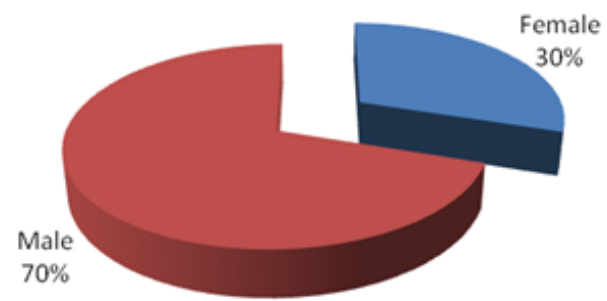

Fig. 2: Gender distribution in the study $(n=10)$

Table 1: Age group distribution of the patients $(\mathbf{n = 1 0})$

\begin{tabular}{|l|c|c|}
\hline Age group & Number of cases & Percentage \\
\hline 20-40 years & 1 & 10 \\
\hline $41-60$ years & 4 & 40 \\
\hline$>60$ years & 5 & 50 \\
\hline
\end{tabular}

Two patients had history of trauma, both were males. The study eye was right eye in $60 \%$ and left eye was in $40 \%$ percent. Out of total ten patients, one patient $(10 \%)$ had traumatic subluxated cataract, one (10\%) had dislocated cataract with no history of trauma and one $(10 \%)$ had traumatic subluxated PCIOL (Fig. 3), rest seven $(70 \%)$ patients had suffered an inadvertent rent of the posterior capsule during cataract extraction (Fig. 4).



Fig. 3: A patient with subluxated posterior chamber intraocular lens 


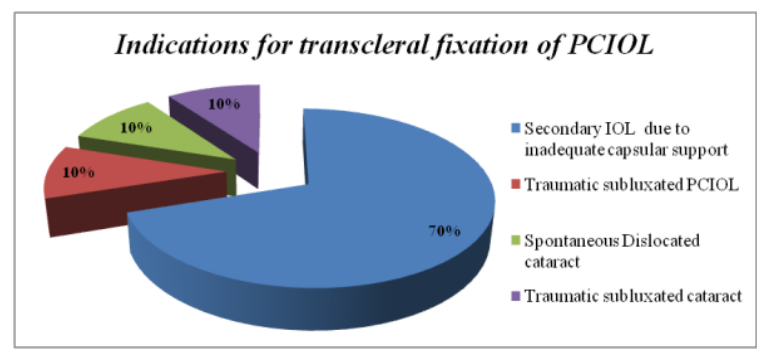

Fig. 4: Indications for transcleral fixation of posterior chamber intra ocular lens (SF-PCIOL)

Out of 10 patients $8(80 \%)$ patients had undergone surgery in the past. One patient underwent phacoemulsification with PCIOL implantation, six patients underwent ECCE / Phacoemulsification without IOL and One had undergone ECCE followed by pars plana vitrectomy and nucleus removal due to nucleus drop. Out of ten eyes, four patients $(40 \%)$ had preoperative BCVA 6/9 (log MAR, 0.18) and rest of six patients $(60 \%)$ had preoperative BCVA 6/12 (log MAR, 0.30) (Table 2). Mean preoperative UCVA in log MAR was 1.52 ( $\mathrm{SD}, \pm 0.41$ ). Mean preoperative BCVA in Log MAR was 0.25 (SD, \pm 0.06 ). Mean preoperative spherical equivalent was $8.37(\mathrm{SD}, \pm 4.79)$ diopters (D). Mean preoperative cylindrical equivalent was 1.05 (SD, \pm 1.88 ) D.

Table 2: Preoperative BCVA distributions in study eye

\begin{tabular}{|c|l|c|c|}
\hline $\begin{array}{c}\text { S. } \\
\text { No. }\end{array}$ & $\begin{array}{l}\text { BCVA* Snellen }( \\
\log \text { MAR })^{* *}\end{array}$ & $\begin{array}{c}\text { No. of patients } \\
(\mathbf{n})\end{array}$ & $\begin{array}{c}\text { Percentage } \\
(\%)\end{array}$ \\
\hline 1 & $\geq 6 / 6(\geq 0.00)$ & 0 & 0 \\
\hline 2 & $\begin{array}{l}6 / 9->6 / 12 \\
(0.18->0.30)\end{array}$ & 4 & 40 \\
\hline 3 & $6 / 12(0.30)$ & 6 & 60 \\
\hline 4 & $<6 / 12(<0.30)$ & 0 & 0 \\
\hline
\end{tabular}

Pars Plana vitrectomy \& Secondary SF-PCIOL implantation was done in seven $(70 \%)$ patients. Parsplana lensectomy \& vitrectomy with transscleral fixation of PCIOL (SF-PCIOL) was done in two (20\%) patients. PCIOL disinsertion and transscleral fixation of PCIOL (SF-PCIOL) was done in one (10\%) patients.
On the $1^{\text {st }}$ postoperative day, $30 \%$ patients had BCVA 6/9 (log MAR, 0.18), 20\% had BCVA 6/12 (log MAR, 0.30), 30\% patients had BCVA 6/18(log MAR, 0.48) and in $20 \%$ patients BCVA was < 3/60 (log MAR, $<1.30)$ (Table 3).

Table 3: Comparison of best corrected visual acuity (BCVA) on subsequent visits

\begin{tabular}{|l|c|c|c|c|c|}
\hline \multicolumn{1}{|c|}{$\begin{array}{c}\text { BCVA } \\
\text { Snellen } \\
(\text { log MAR) }\end{array}$} & $\begin{array}{c}\text { BCVA } \\
\text { Pre op* }\end{array}$ & $\begin{array}{c}\text { BCVA } \\
\text { Post op** } \\
\text { Day 1 }\end{array}$ & $\begin{array}{c}\text { BCVA } \\
\text { Post op } \\
\text { Wk 1 }\end{array}$ & $\begin{array}{c}\text { BCVA } \\
\text { Post op } \\
\text { Wk 6 }\end{array}$ & $\begin{array}{c}\text { BCVA } \\
\text { Post op } \\
\mathbf{3}^{\text {rd }} \text { month }\end{array}$ \\
\hline$\geq 6 / 6(0.00)$ & $0(0 \%)$ & $0(0 \%)$ & $1(10 \%)$ & $1(10 \%)$ & $1(10 \%)$ \\
\hline $\begin{array}{l}6 / 9->6 / 12(0.18 \\
->0.30)\end{array}$ & $4(40 \%)$ & $3(30 \%)$ & $6(60 \%)$ & $7(70 \%)$ & $7(70 \%)$ \\
\hline $\begin{array}{l}6 / 12->6 / 18 \\
(0.30->0.48)\end{array}$ & $6(60 \%)$ & $2(20 \%)$ & $2(20 \%)$ & $2(20 \%)$ & $2(20 \%)$ \\
\hline $\begin{array}{l}6 / 18->6 / 24 \\
(0.48->0.60)\end{array}$ & $0(0 \%)$ & $3(30 \%)$ & $1(10 \%)$ & $0(0 \%)$ & $0(0 \%)$ \\
\hline $\begin{array}{l}6 / 24->6 / 36 \\
(0.60->0.78)\end{array}$ & $0(0 \%)$ & $0(0 \%)$ & $0(0 \%)$ & $0(0 \%)$ & $0(0 \%)$ \\
\hline $\begin{array}{l}6 / 36->6 / 60 \\
(0.78->1.00)\end{array}$ & $0(0 \%)$ & $0(0 \%)$ & $0(0 \%)$ & $0(0 \%)$ & $0(0 \%)$ \\
\hline $\begin{array}{l}6 / 60->3 / 60 \\
(1.00->1.30)\end{array}$ & $0(0 \%)$ & $0(0 \%)$ & $0(0 \%)$ & $0(0 \%)$ & $0(0 \%)$ \\
\hline $\begin{array}{l}\leq 3 / 60 \\
(\leq 1.30)\end{array}$ & $0(0 \%)$ & $2(20 \%)$ & $0(0 \%)$ & $0(0 \%)$ & $0(0 \%)$ \\
\hline
\end{tabular}

*Pre op - Pre operative, **Post op - Post operative

On the $3^{\text {rd }}$ month postoperative day $70 \%$ had BCVA 6/9 (log MAR, 0.18), 20\% patients had BCVA 6/12(log MAR, 0.30) and 10\% patients had BCVA 6/6 (log MAR, 0.00). Postoperative BCVA was stabilized on $6^{\text {th }}$ week postoperative day. Four patients $(40 \%)$ had preoperative BCVA 6/9 (log MAR, 0.18). Out of these in three patients (30\%) BCVA was maintained while in one patient $(10 \%)$ BCVA was decreased on the $3^{\text {rd }}$ month postoperative day. Six patients $(60 \%)$ had preoperative BCVA $6 / 12(\log$ MAR, 0.30). Out of 
these in five patients (50\%) BCVA was increased while in one patient $(10 \%)$ BCVA was maintained on the $3^{\text {rd }}$ month postoperative day.

\section{End result in efficacy}

The final BCVA was increased in 50\% patients, maintained or unchanged in $40 \%$ patients, while in $10 \%$ patient BCVA was decreased on the $3^{\text {rd }}$ month postoperative day (Table 4).

Table 4: Comparison of Preoperative BCVA and final postoperative BCVA at $3^{\text {rd }}$ month

\begin{tabular}{|c|c|c|c|c|}
\hline S. No & $\begin{array}{c}\text { Baseline pre op BCVA } \\
\text { Snellen ( log MAR ) }\end{array}$ & $\begin{array}{c}\text { No. of patients } \\
(\mathbf{n})\end{array}$ & $\begin{array}{c}\text { Post op Month 3 BCVA } \\
\text { Snellen (log MAR ) }\end{array}$ & $\begin{array}{c}\text { No. of patients } \\
\text { (n) }\end{array}$ \\
\hline \multirow{2}{*}{1} & \multirow{2}{*}{$6 / 9(0.18)$} & $4(40 \%)$ & $6 / 9(0.18)$ & $3(30 \%)$ \\
& & & $6 / 12(0.30)$ & $1(10 \%)$ \\
\hline \multirow{2}{*}{2} & \multirow{2}{*}{$6 / 12(0.30)$} & $6(60 \%)$ & $6 / 6(0.0)$ & $1(10 \%)$ \\
& & & $6 / 9(0.18)$ & $4(40 \%)$ \\
\end{tabular}

Mean log MAR BCVA was changed from 0.25( \pm $0.06)$ to $0.19(\mathrm{SD}, \pm 0.08 ; \mathrm{p}=0.10$ ) in our study. Mean spherical equivalent significantly changed from 9.41 $(\mathrm{SD}, \pm 4.05)$ to-1.1 (SD $\pm 1.94 ; \mathrm{p}=.004)$. In contrast, the mean cylindrical equivalent changed from 1.56 (SD, $\pm 1.32)$ to $1.58(\mathrm{SD}, \pm 1.05 ; \mathrm{p}=0.73)$. The change in mean cylindrical equivalent was not statistically significant.

Preoperatively the lowest CMT recorded was $202.00 \mu$ and the highest was $240.00 \mu$. The mean CMT was $221.60(\mathrm{SD}, \pm 10.12) \mu$.

On the $1^{\text {st }}$ postoperative mean CMT was $227.40(\mathrm{SD}, \pm 8.33) \mu$.On the $1^{\text {st }}$ week postoperative day mean CMT on the $1^{\text {st }}$ week postoperative day was $225.90(\mathrm{SD}, \pm 5.40) \mu$. On the $6^{\text {st }}$ week postoperative day mean CMT was $222.90(\mathrm{SD}, \pm 7.80) \mu$. On the $3^{\text {rd }}$ month postoperative day the lowest CMT recorded was $205.00 \mu$ and the highest was $242.00 \mu$. The mean CMT was $224.30 \pm 10.23 \mu$.

All patients had normal IOP preoperatively. The mean preoperative IOP was $13.80 \pm 3.12 \mathrm{~mm}$ of $\mathrm{Hg}$. On the $1^{\text {st }}$ postoperative day, the mean postoperative IOP was $13.20(\mathrm{SD}, \pm 3.12) \mathrm{mm}$ of $\mathrm{Hg}$ On the $1^{\text {st }}$ week postoperative day the mean IOP on the $1^{\text {st }}$ week postoperative day was $12.6(\mathrm{SD}, \pm 3.47) \mathrm{mm}$ of $\mathrm{Hg}$. On the $6^{\text {st }}$ week postoperative day the mean IOP on was $13.6(\mathrm{SD}, \pm 3.13) \mathrm{mm}$ of mercury. On the $3^{\text {rd }}$ month postoperative day the mean IOP was $12.7(\mathrm{SD}, \pm 2.49)$ $\mathrm{mm}$ of $\mathrm{Hg}$.

The mean endothelial cell count was 2430.70 (SD, $\pm 664.97)$ cells $/ \mathrm{mm}^{2}$ preoperatively. The mean ECC was $2407.70(\mathrm{SD}, \pm 660.24)$ cells $/ \mathrm{mm}^{2}$ on the $1^{\text {st }}$ postoperative day, $2407.7(\mathrm{SD}, \pm 665.65)$ cells $/ \mathrm{mm}^{2}$ on the $1^{\text {st }}$ week postoperative day and on the $6^{\text {th }}$ week postoperative day mean ECC was 2405.70 (SD, \pm 659.94) cells $/ \mathrm{mm}^{2}$. The final mean ECC was 2405.8 $\left(\mathrm{SD}, \pm\right.$ 663.68) cells $/ \mathrm{mm}^{2}$ on the $3^{\text {rd }}$ month postoperative day.

Striate keratopathy (SK) was developed in one (10\%) patient immediate postoperatively .One (10\%) patient had postoperative inflammation fibrinous reaction. Two patients had haptic exposure and one patient had persistent corneal haze. No other major complications were encountered during the follow-up.

\section{End result of feasibility}

On the $1^{\text {st }}$ postoperative mean CMT was $227.40(\mathrm{SD}, \pm 8.33) \mu$. On the $3^{\text {rd }}$ month postoperative day the mean CMT was $224.30 \pm 10.23 \mu$. All patients had normal IOP preoperatively. The mean preoperative IOP was $13.80 \pm 3.12 \mathrm{~mm}$ of $\mathrm{Hg}$. On the $3^{\text {rd }}$ month postoperative day the mean IOP was $12.7(\mathrm{SD}, \pm 2.49)$ $\mathrm{mm}$ of $\mathrm{Hg}$. The mean endothelial cell count was 2430.70 (SD, \pm 664.97 ) cells $/ \mathrm{mm}^{2}$ preoperatively. . The final mean ECC was $2405.8(\mathrm{SD}, \pm 663.68)$ cells $/ \mathrm{mm}^{2}$ on the $3^{\text {rd }}$ month postoperative day.

\section{Discussion}

In one patient with subluxated cataractous lens visual acuity improved from preoperative BCVA 6/12 to $6 / 6$ postoperative BCVA. While in one patient having subluxated IOL improved from preoperative BCVA 6/12 to postoperative BCVA 6/9.

One patient had posterior dislocated cataractous lens (optical aphakia) with preoperative BCVA 6/9. This patient had same postoperative BCVA but with marked decrease in the visual disability. Rest seven patients had undergone secondary IOL due to inadequate capsular support following a previous complicated cataract surgery. Out of these seven patients, BCVA was improved from $6 / 12$ to $6 / 9$ in three patients, while BCVA was remained same 6/12 and 6/9 postoperatively in two patients with marked decrease in their visual disability. One patient had drop in BCVA from preoperative $6 / 9$ to postoperative $6 / 12$ due to development of striate keratopathy (SK) \& persistent corneal haze postoperatively as this patient had preoperative endothelial cell count in the range of 1500 $2000 \mathrm{cell} / \mathrm{mm}^{2}$.

In our study finally postoperative BCVA was increased in five $(50 \%)$ patients, remained equal in four $(40 \%)$ patients and decreased in one $(10 \%)$ patient. Overall nine $(90 \%)$ patients had an improved or unchanged BCVA and only one patient had reduced BCVA. 
McAllister et $\mathrm{al}^{39}$ in their study of sutured sclera fixated PCIOL on 82 eyes of 72 patients reported improved or unchanged BCVA in 59 eyes $(72 \%)$ and reduced BCVA in 23 eyes (28\%). While Agarwal et al ${ }^{13}$ in their study on glued SF-PCIOL on 10 eyes reported improved BCVA in $4(40 \%)$ eyes and unchanged BCVA in $6(60 \%)$ eyes. And no patient showed drop in BCVA.

In our study the mean improvement in BCVA was, in term of $\log$ MAR units from 0.25 (SD \pm 0.06 ) to 0.19 $(\mathrm{SD} \pm 0.08 ; \mathrm{p}=0.10)$ and also in terms of decimal equivalent from $0.57(\mathrm{SD} \pm 0.09)$ to $0.70(\mathrm{SD} \pm 0.14 ; \mathrm{p}$ $=0.11$. While in study of Agarwal et al ${ }^{12}$ mean preoperative BCVA In decimal equivalent was 0.46 \pm 0.42 , and the mean postoperative BCVA on day 1 was $0.50 \pm 0.38$. At 6 weeks, the mean BCVA was $0.50 \pm$ 0.37 . In a study by Bading et $\mathrm{a}^{16}$ of scleral-fixated sutured posterior chamber lens (PC IOL) in 63 patients revealed improvement in mean BCVA in $\log$ MAR from 1.025 ( $\mathrm{SD}, 0.654)$ to $0.766(\mathrm{SD}, 0.750 ; \mathrm{P}, .03)$.

\section{Refractive analysis}

In our study, mean spherical equivalent in refractive analyses significantly changed from $9.41 \pm$ 4.05 diopters $(\mathrm{D})$ to $-1.1 \pm 1.94 \mathrm{D}(\mathrm{p}=0.004)$. The mean cylindrical equivalent changed from $1.56 \pm 1.32 \mathrm{D}$ to $1.58 \pm 1.05 \mathrm{D}(\mathrm{p}=0.73)$, which was not statistically significant. One patient had striate keratopathy as immediate postoperative complication on the first postoperative day, so refraction of that patient could not be done on the first postoperative day. In a study by Bading et $\mathrm{al}^{16}$ of scleral-fixated sutured posterior chamber lens (PC IOL) in 63 patients reported change in mean spherical equivalent was from preoperative $0.33(\mathrm{SD}, \pm 0.44)$ to postoperative $-0.43(\mathrm{SD}, \pm 1.63$; $\mathrm{p}$ $=0.44)$ and change in mean cylindrical equivalent was from - $0.92(\mathrm{SD}, \pm 1.07)$ to $-1.76(\mathrm{SD}, \pm 1.34 ; \mathrm{p}=.005)$. The analysis of refraction was not reported in studies of glue assisted transscleral fixation of posterior chamber intraocular lens (SF-PCIOL).

\section{Intraocular pressure (IOP)}

The mean preoperative IOP was $13.80 \pm 3.12 \mathrm{~mm}$ of $\mathrm{Hg}$, while the mean IOP on the $3^{\text {rd }}$ month postoperative day was $12.7 \pm 2.49 \mathrm{~mm}$ of $\mathrm{Hg}$. There was statistically significant change in the mean IOP $(\mathrm{p}=0.03)$. But no evidence of post operative raised IOP was noted. Agarwal et $\mathrm{al}^{12}$ in their study on glued SFPCIOL on 10 eyes reported no significant change in the mean intraocular pressure. It was from $11.3(\mathrm{SD} \pm 2.41)$ to 11.6 ( $\mathrm{SD} \pm 1.35$ ).Kumar et al ${ }^{17}$ study of glued SFPCIOL on 53 eyes also reported no significant change in the mean intraocular pressure.

\section{Endothelial cell count (ECC)}

In our study the mean endothelial cell count was changed from 2430.70 (SD, \pm 664.97) to 2405 (SD, \pm 663.68) cells $/ \mathrm{mm}^{2}$. The mean percentage change in endothelial cell count was $-1.02 \% \pm 5.52 \%$ cells $/ \mathrm{mm}^{2}$, which was statistically significant $(\mathrm{p}=<0.001)$ in our study. While in Agarwal et $\mathrm{al}^{12}$ study the mean percentage change in the endothelial cell count was $1.64 \% \pm 1.29 \%$ cells $/ \mathrm{mm}^{2}$. In Kumar et $\mathrm{al}^{17}$ study of glued SF-PCIOL on 53 eyes also reported percentage (\%) loss of endothelial cells was $5.23 \pm 3.4 \%$ at 1 -year.

\section{Central macular thickness (CMT)}

In our study there was statistically significant change in the mean central macular thickness from preoperative $221.60(\mathrm{SD}, \pm 10.12) \mu$ to $224.30(\mathrm{SD}, \pm$ $10.23 ; p=0.01) \mu$, and no evidence of chronic macular edema (CME) was noted. In Agarwal et al ${ }^{12}$ study also there was no case of chronic macular edema reported in 6 week follow up, while CME was reported in 3 eyes $(1.4 \%)$ in 1 year follow up of Kumar et al ${ }^{17}$ study of 53 eyes.

\section{Post operative complications}

Two patients who had pigment release intraoperatively also develop immediate complications (first 48 hour). Of these one had striate keratopathy (SK) / corneal oedema and one had significant postoperative inflammation. Of these, one patient had persistent postoperative inflammation on the $1^{\text {st }}$ week postoperative day, which was resolved over the next few days with topical steroid antibiotic drops. Remaining one patient had persistent striate keratopathy on the $1^{\text {st }}$ week postoperative day.

The late post operative complications (6 weeks onwards) were seen in three patients. Out of these, one patient had persistent corneal haze developing after SK. In two patients haptic exposure was found on slit lamp examination on routine follow up visit. These patients were managed medically and surgically accordingly (Fig. 5).

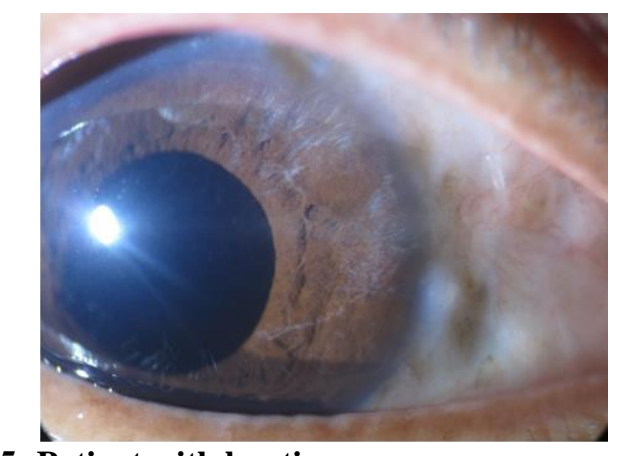

Fig. 5: Patient with haptic exposure

In our study two patients had haptic extrusion in the follow up visit. Other studies of glued SF- PCIOL did not report this complication. This may be because we used 3 piece IOLs.

Agarwal et al ${ }^{12}$ in their study on glued SF-PCIOL on 10 eyes reported no postoperative complications such as postoperative inflammation, hyphema, 
decentration, glaucoma, corneal edema, or fibrin glueinduced reaction in 6 week follow up. Kumar et al ${ }^{17}$ study of glued SF-PCIOL on 53 eyes reported decentration $(5.6 \%)$, pigment dispersion (3.7\%) and healed macular oedema $(7.5 \%)$. Kumar et $\mathrm{al}^{18}$ retrospective evaluated 210 patients who underwent glued intra ocular lens implantation from December 2007 to August 2010 and conclude that glued IOL seems to be a good alternative in IOL implantation in eyes with deficient capsules.

\section{Conclusion}

Fibrin glue has several advantages over Sutured Scleral Fixated IOL, when used as bioadhesive in suture less cataract surgery. It reduces surgical time, has adequate bond strength, acts as a good sealant, minimal allergic or toxic reactions, minimizes bleeding and does not produce inflammation.

To bring this technique in usual practice this study should be conducted at a larger level and that too with a longer follow up of the patients to see visual outcome as well as complications.

\section{Limitations}

The sample size of the present study is small and is difficult to be compared with techniques of sutured SFPCIOL.

Funding: No funding sources.

Conflict of interest: None declared.

\section{References}

1. Bleckmann H, Hanuschik W, Vogt R.Implantation of posterior chamber lenses in eyes with phakodonesis and lens subluxation. J Cataract Refract Surg 1990;16:48589.

2. Fries UK, Ohrloff C.Ultrasound biomicroscopy_image of the capsule supporting ring in pseudophakia. Klin Monatsbl Augenheilkd 1996;209(4):211-14.

3. Smith PW, Wong SK, Stark WJ, Gottsch JD, Terry AC, Bonham RD. Complications of semi-flexible, closed-loop anterior chamber intraocular lenses. Arch Ophthalmol 1987;105:52-7.

4. Wagoner MD, Cox TA, Ariyasu RG, Jacobs DS, Karp CL, American Academy of Ophthalmology. Intraocular lens implantation in the absence of capsular support: a report by the American Academy of Ophthalmology. Ophthalmol 2003;110:840-59.

5. Arkin MS, Steinert RF: Sutured posterior chamber intraocular lenses. Int Ophthalmol Clin 1994;34:67-85.

6. Bleckmann H, Hanuschik W, Vogt R: Implantation of posterior chamber lenses in eyes with phakodonesis and lens subluxation. J Cataract Refract Surg 1990;16:485-9.

7. Solomon KD, Apple DJ, Mamalis N, et al: Complications of intraocular lenses with special reference to an analysis of 2500 explanted intraocular lenses (IOLs). Eur J Imp Refract Surg 1991;3:195-200.

8. Kwong YY,Yuen HK, Lam RF, Lee VY, Rao SK, Lam DS. Comparison of outcomes of primary scleral-fixated versus primary anterior chamber intraocular lens implantation in complicated cataract surgeries. Ophthalmol 2007;114:80-5.

9. Gabor SGB, Pavilidis MM. Sutureless intrascleral posterior chamber intraocular lens fixation. $J$ Cataract Refract Surg 2007;33:1851-54.

10. R. Maggi \& C. Maggi. Sutureless scleral fixation of intraocular lenses. J Cataract Refract Surg 1997;23(9):1289-94.

11. Wallmann AC, Monson BK, Adelberg DA. Transscleral fixation of a foldable posterior chamber intraocular lens. J Cataract Refract Surg 2015;41:1804-09.

12. Agarwal A, Kumar DA, Jacob S, Baid C, Agarwal A, Srinivasan S. Fibrin glue-assisted sutureless posterior chamber intraocular lens implantation in eyes with deficient posterior capsules. J Cataract Refract Surg 2008; 34(9):1433-38.

13. Fink D, Klein JJ, Kang H, Ergin MA. Application of biological glue in repair of intracardiac structural defects. Ann Thorac Surg 2004;77:506-11.

14. Mintz PD, Mayers L, Avery N, Flanagan HL, Burks SG,Spotnitz WD. Fibrin sealant: clinical use and the development of the University of Virginia Tissue Adhesive Center. Ann Clin Lab Sci 2001;31:108-18.

15. Prakash G, Agarwal A, Kumar DA, Saleem A, Jacob S, Agarwal A. Translocation of malpositioned posterior chamber intraocular lens from anterior to posterior chamber along with fibrin glue-assisted transscleral fixation. Eye Contact Lens 2010;36(1):45-8.

16. Bading G, Hillenkamp J, Sachs HG, Gabel VP. Long term Safety and Functional Outcome of Combined Pars Plana Vitrectomy and Scleral-Fixated Sutured Posterior Chamber Lens Implantation Am J Ophthalmol 2007;144:371-77.

17. Kumar DA, Agarwal A, Prakash G, Jacob S, Saravanan Y, Agarwal A. Glued posterior chamber IOL in eyes with deficient capsular support: a retrospective analysis of 1year post-operative outcomes. Eye (Lond) 2010;24(7):1143-48.

18. Kumar DA, Agarwal A, Agarwal A, Prakash G, Jacob S. Glued intraocular lens implantation for eyes with defective capsules a retrospective analysis of anatomical and functional outcome. Saudi J Ophthalmol 2011;25:245-54.

How to cite the article: Srivastava G., Goel N., Arora A.
Efficacy and safety of glue assisted suture less trans-
scleral fixation of posterior chamber intraocular lens (SF-
PCIOL). Int J Ocul Oncol Oculoplasty 2018;4(3):132-
137.

